\title{
Basel III, Clubs and Eurozone Asymmetries
}

\author{
Michele Fratianni* and John Pattison**
}

\begin{abstract}
$\underline{\text { Abstract }}$
Financial regulation has shifted from a system managed as an oligopoly dominated by the G2/G5 to expanded club membership like the Basel Committee for Banking Supervision (BCBS). Expansive clubs have to agree to terms that are closer to the preferences of softregulation members. Yet, once a global agreement on minimum standards, such as Basel III, is reached, the implementation is left to national or regional regulators. Deviations from the Basel III standards are bound to occur; the complexity of the agreement will facilitate an asymmetric implementation of national regulation and supervision. On the high side, countries like the US, UK, Australia, some Scandinavian countries and Canada have chosen higher standards. On the low side, we expect deviations to take place in those member countries of the Eurozone that are heterogeneous, have different preferences and tradeoffs between regulatory stringency and economic activity. The requirements of both global clubs and the EU regional club for transparency, monitoring and a level playing field will cause a collision between the interests of the clubs and their members, threatening to undermine global standard setting at the BCBS.
\end{abstract}

Key Words: Basel III, clubs, financial regulation, Eurozone, asymmetries. JEL Classification Numbers: F33, F36, F42

\footnotetext{
* Indiana University, Kelley School of Business, Business Economics and Public Policy Bloomington, Indiana 47405 (USA) and Università Politecnica delle Marche Economics Department, Ancona (Italy), email:fratiann@indiana.edu; **Retired banker and faculty, Toronto, Canada.
} 


\section{I.INTRODUCTION}

The oversight of financial markets has been under scrutiny since the crisis. The asymmetries in the Eurozone (EZ) and the sovereign debt crisis in the EZ periphery have caused political tensions arising from different preferences among member countries for tighter regulation versus short-term economic growth. These tensions created pressure for a weaker and delayed implementation of regulation agreed among European countries with the two financial clubs with an expansive membership, the Basel Committee on Banking Supervision (BCBS) and the Financial Stability Board (FSB). ${ }^{1}$

These committees are in essence extended financial clubs that shape the approaches, methodology, quantification and calibration of regulation across countries. They create a public good in the form of international financial standards (Kindleberger 1983). ${ }^{2}$ Standards generate economies external to the firm and reduce transactions costs by lowering risk and uncertainty. They may be implemented by producers rather than imposed by governments. ${ }^{3}$ Today, the best argument for financial regulation rests on network effects. Individuals and institutions suffer from asymmetric information and cannot properly assess the credit risk of their counterparties in a financial transaction. In times of financial turmoil, mistrust in counterparties becomes paramount, as demonstrated in the aftermath of the failure of Lehman Brothers in October of 2008.

The performance of financial clubs is sensitive to specific shocks or problems that affect the types of regulation and their timing in individual countries. Performance is also

\footnotetext{
${ }^{1}$ See Table $1 \mathrm{~A}$ in the Appendix for a list of clubs, membership and their functions.

${ }^{2}$ Kindleberger's characterization is that "they are a strong form of public good in that they have economies of scale." (1983:377).

${ }^{3}$ On this, Kindleberger points out that "Governmental standards may turn out to be dubious public goods and at the same time collective bads." (1983:381).
} 
sensitive to the composition of an expanded membership that accentuates club heterogeneity: the economic incentives of new, smaller, and less financially-intensive members do not match those of the old, large, and financially-intensive members. Conflicts arising from membership heterogeneity imply that European financial clubs face a difficult task in achieving common regulatory standards. Because of these conflicts four issues stand out. The first is that the single market demands a common regulatory framework to avoid distorting competition. Yet in a heterogeneous club with members with different preferences for regulation and other economic variables, the implementation of a single standard will not be feasible. National preferences for regulation are shaped by the relative importance of the banking sector, tradeoffs between regulatory stringency and other macroeconomic objectives, the intensity of industry lobbying for weaker regulation and governments' capacity to resist. The second is that in an incomplete and fragile monetary union like the EZ, large members are exposed to the financial risks emanating from fiscally undisciplined members. This may occur through many channels, such as the widespread use of government debt of countries with varying degrees of creditworthiness yet sharing a common currency. It should be stressed in this context that the implementation of international regulatory standards may have little to do with the ultimate survival of the EZ, which instead depends on concrete and timely progress towards the formation of a banking union and a fiscal union. The third is that in a financial crisis, political pressure is exerted to soften regulation to help weaker members to protect undercapitalized institutions and to stimulate the economy; the pressure is larger the greater the asymmetries in the impact of the crisis across member states. The last is the intersection of regional and global regulatory clubs: the heterogeneity of a regional club compounds the already difficult bargaining 
process with other countries, regional clubs and international organizations to achieve common global financial standards. The tensions in regional clubs threaten compliance with bargains negotiated in larger global clubs, which in turn undermines the ability of larger bodies to sell common regulatory standards.

The rest of the paper proceeds as follows. We start in Section II with an analysis of the shift from oligopoly-type clubs to expansive clubs in generating international cooperation on financial regulation. We then outline, in Section III, the main elements of the complex Basel III agreement and the differences in its implementation in two large economic areas, the EU and the US. In Section IV we discuss the conflict between the single rulebook, the common standard underlying the single market for banking, desired by EU policy makers, and the drive of member countries to implement the rulebook flexibly. Flexible implementation, in turn, is driven by an incomplete and fragile EZ construction and significant member country heterogeneity in economic structure and regulatory preferences. Conclusions are drawn in Section V.

\section{II.OLIGOPOLY POLICY FORMATION VS. REGULATION BY COMMITTEE}

After the Second World War the largest countries initiated cooperative actions, governed important international organizations, structured and negotiated policy changes, often behind closed doors, and were essential in implementing and disseminating the policies. In the regulatory field, "it is hard to think of international standards that did not start out as the public good of some particular country, usually one with high international standing because of its economic and/or military power" (Kindleberger 1983:392). Originally, the G-5, G-7 and G-10 were the key small-number clubs. The capital rules of the Basel I 
Accord of 1988 were worked out between the United States (US) and the United Kingdom (UK) and then sold to other countries through the auspices of BCBS. Basel II and Basel III Accords, developed during the first decade of the $21^{\text {st }}$ century, are instead products of expansive committees. In less than twenty years we have moved from a decision-making process dominated by few critical players, organized in small and homogeneous clubs, to a process where agreements and decisions are taken within the setting of large-number clubs. In the case of the important BCBS and FSB, membership expansion has taken place by including a growing number of countries with relatively small financial sectors; see Table $1 \mathrm{~A}$ in the Appendix.

Cooperation in financial regulation occurs if countries expect to receive net benefits from it. Under those conditions, they are willing to invest political and financial capital. An oligopoly of nations creates incentives for large countries to lead in the cooperative effort. This is so because large countries, by virtue of their size, gain the most from cooperation and consequently are willing to bear proportionately higher costs to achieve it. Since costs occur before benefits, a large country will invest in cooperation if it is reasonably sure to obtain sufficiently large benefits to justify the investment. Small countries, on the other hand, generate small policy contributions to the club and tend to free ride on the policies and investments made by large countries; free-riding is facilitated by their small policy contributions. As Olson aptly put it (1973: 24): "What matters most is not how much of the collective good will be provided if some is provided, but rather whether any of the collective good will be provided." That is, the conditions for the creation of cooperative action are restrictive and free-riding behavior needs to be managed. Olson's insight is that the conditions for cooperation are limiting. However, in the European case the regulatory 
club had been created prior to the divisive tensions arising from the financial and sovereign debt crises. One implication is that new agreements would not deliver benefits to EU countries with vastly different needs and preferences. The negotiating challenge is to agree to international standards while achieving national or regional aims. This may be achieved in a number of ways, for example by agreeing to lower commitments, by delays in implementation, opaqueness, or leaving sufficient discretion to avoid full compliance.

In the search for the optimum amount of cooperation there is a difference between what an individual country wants and a group of countries may wish (Fratianni and Pattison 1982). Each member makes a decision to maximize net benefits (likely in the form of marginal policy contributions which translate into economic and financial gains) from membership. In a symmetric world populated by a large number of small countries, the contribution of an individual country to a cooperative activity, in terms of both information content and policy contribution, would be small. A club could not be created or sustained because incentives for cooperation would be diffused across many issues unrelated to one another. The model would predict decreasing cooperation as financial markets become more dispersed. In an asymmetric world, populated by a few large countries and many small countries, the contribution to a cooperative activity of some countries becomes economically significant. These incremental benefits decline as large countries add smaller countries to the club. But as countries are added the likelihood of conflicts among members rises and so do the costs of sharing and interpreting more complex information, as well as of decision-making processes; in essence, marginal costs in running the club rise. Thus, the optimal number of members in a club is determined by the interaction of how fast marginal benefits from cooperation decline and marginal costs rise as new members are added. 
Naturally, there is more to financial oligopolies than the number of players. Other issues cover: the origination of cooperative activity; the payoff and reaction matrices and, how the game is played by clubs; the incentives and behavior of big and small members; the operations and policy recommendations of international organizations and how these influence club members, in particular to questions of funding, structure, governance and voting. Our assessment is that the oligopoly model accounts for a great deal of cooperative origination in the context of Bretton Woods institutions. During the fixed exchange rate regime of the gold-dollar exchange standard, member countries valued knowledge about current and future economic developments in the US, the UK, Germany and Japan. This informational process was enhanced by inter-governmental meetings where member countries would receive "private" information on political attitudes and economic policy in the critical countries. The G-10 group of countries, created in 1961, played a strong role in the IMF, the OECD, and the BIS. Participation in the OECD important Working Party 3, dealing with balance of payments, was restricted to the G-10, the European Union, and two observers, the IMF and the BIS. The central banks of the G-10 countries met (and continue to meet), without much publicity but great effectiveness, once a month at the BIS (Fratianni and Pattison 2001). The G-5, a sub-group of the G-7 created in 1973, achieved significant exchange rate coordination in the mid 1980s and their activities paved the way for the IMF to engage in so-called multilateral surveillance (Boughton 2001:ch. 4). ${ }^{4}$

We have noted that global standards have moved from an oligopoly setting with Basel I to an expanded-club setting with Basel II and III. The inference is that the economics and the politics no longer favor the roles and incentives of industrial countries

\footnotetext{
${ }^{4}$ For details of the two exchange rate accords, the Plaza of 1985 and Le Louvre of 1987, see Funabashi (1988).
} 
with large and dominant global financial markets initiating the rules. Several factors are at play. The first is legitimacy. Small clubs exude secrecy and exclusion. Those who are excluded clamor for a more democratic approach. Large countries may have felt the pressure of world opinion turning against them. To this pressure has contributed the widely held view that the regulatory frameworks of the US and the UK have been tarnished by the financial crisis. The consequent loss of reputational capital weakened the leadership of these two countries in initiating global rules and in sustaining the success of small-number financial clubs.

But there is more than political pressure in membership expansion. Economic power has shifted from the core industrial countries, defined by membership in clubs like the G-5 or G-7, to emerging market economies, defined by a country grouping like BRIC (Brazil, Russia, India and China). During the Bretton Woods period, the G-5 group-consisting of the United States, the United Kingdom, Germany, France and Japan-held an extremely high and constant share of approximately 85 percent of OECD GNP (Fratianni and Pattison 1982, Table 2). ${ }^{5}$ Today, the economic power of core industrial countries, while remaining considerable, has declined significantly relative to emerging market economies; see Table 1B in the Appendix.

The third reason for membership expansion stems from the fact that with the globalization of financial markets more countries have become active in updating national financial regulation. In terms of the club model, this implies that the marginal benefits schedule from cooperation has shifted upward, in turn justifying an expansion of the number of players in international rule making. The fourth reason is that the growth of financial institution subsidiaries from large countries to less regulated locations has raised

\footnotetext{
${ }^{5}$ We are using world GNP or GDP shares as a proxy of the club's policy contribution.
} 
the benefit to large countries to be more inclusive in setting global standards. Global institutions lower their costs when regulation is more homogeneous; also homogeneous regulation must satisfy lower standards to be agreed by a number of countries. The final reason has to do with one of the assumptions of the traditional club model, namely that the inclusion of a small country in a club generates negligible marginal value of information and policy contribution, while raising considerably the marginal cost of decision making to the club as a whole and to individual members. The relative irrelevance of small countries in a club is based on the assumption that these countries do not create significant economic and political spillovers; it would behoove the club to include them and set rules that would minimize the occurrence of conditions that would lead to such spillovers.

The larger countries with significant international financial institutions are at risk from network externalities: risks from counterparties' transactions with risky but unobservable counterparties. Thus the prudential case for global standards has a basis in systemic risk reduction.

Greece is an example of significant spillovers from a small to large member countries of a monetary club. In December 2009, Greece, which had suppressed information about the size of it government budget deficit, received a sharp credit rating downgrade. This, in turn, triggered massive capital outflows and sudden-stop episodes, not only in Greece, but in the Southern countries of the EZ (Merler and Pisani-Ferry 2012). Sovereign bond yields in these countries suffered a steep rise in a period of otherwise stable or moderately declining global risk aversion (Alessandrini et al. 2014 forthcoming). This is a classic case of a small country imposing negative information value on other club members. The reason for the spillovers has to do with an inadequate and thereby flawed, 
adjustment mechanism in the EZ (Dellas and Tavlas 2013). In the international gold standard, countries that adhered to it faced an effective balance-of-payments constraint: when the fundamentals of fiscal policy deteriorated sovereign credit risk and domestic interest rates rose, prompting policy makers to take corrective actions that would restore equilibrium in the balance of payments. This mechanism has not been present in the EZ. Greece, but also other member countries, for a long time were not penalized by the financial markets for their poor fundamentals because of a presumption that fiscally profligate countries would be bailed out. In sum, a faulty design mechanism, coupled with incorrect market expectations on creditworthiness, was responsible for a "deviating" small member country to impose large negative spillovers onto larger member countries.

\section{III.BASEL III, COMPLEXITY AND THE SINGLE RULEBOOK}

Basel III has been in the making for quite some time beginning with the move to Basel II which commenced in 1999. While refinements to this agreement will continue to be made, its main structure is in place. Implementation at the national and regional level is well underway. The US has approved its own new set of regulations under the rubric of "Final US Rules" that incorporate Basel III norms as well as provisions of the Dodd-Frank Act (Board of Governors of the Federal Reserve System, Basel Regulatory Framework, http://www.federalreserve.gov/bankinforeg/basel/USImplementation.htm\#baseIII). The EU has taken the international agreement through the BCBS on Basel III to create its own Capital Requirement Regulation and a Capital Requirement Directive, jointly known as CRD IV, which entered into force on July 17, 2013 (European Commission 2013b). Twenty-five of the twenty-seven jurisdictions that are members of the BCBS have issued Basel III capital regulations (BCBS 2013). 
Despite the immense effort that has gone into the Basel III agreement, we expect significant differences in implementation, interpretation and enforcement across countries. Basel III sets minimum standard levels and countries are free to choose tougher standards. Banking centers that want to establish or maintain a high safety reputation may decide to go above the minimum levels agreed by an expansive club whose members are heterogeneous in their regulatory preferences. The EU is aware of this outcome and has been keen at eliminating the threat of member country differences in regulatory standards. In June of 2009, the Council of the European Union (2009) recommended establishing a single rulebook for all financial institutions in the single market. ${ }^{6}$ In 2013 , the European Commission (2013a:2) stated the single rulebook is "crucial to ensure that there are no loopholes and good regulation everywhere in order to guarantee a level playing field for banks and a real single market for financial services." In 2014, the Eurozone will be launching, after extensive stress tests, a banking union composed of approximately 130 globally systemically important banks. These banks will be subject to a single supervisor and thus a consistent set of rules is expected to prevail. The bulk of the EZ banking system, on the other hand, will be supervised by national authorities, with the understanding that there will close coordination of rules and procedures. The European Banking Authority (EBA) has been charged to ensure consistency in the rulebook. But as with any other regulation, the question is whether reality will meet the objectives. We will argue that different national preferences for

\footnotetext{
${ }^{6}$ On page 8, the document states: “...the European Council agrees that the European System of Financial Supervisors should have binding and proportionate decision-making powers in respect of whether supervisors are meeting their requirements under a single rule book and relevant Community law and in the case of disagreement between the home and host state supervisors, including within colleges of supervisors."
} 
regulation, coupled with the complexity of Basel III, will yield substantial regulatory heterogeneity across countries.

Table 1 below summarizes how the main parts of Basel III have been implemented, as of the end of 2013, in two large economic areas of the world, the EU and the US. The table, naturally, cannot do justice to the scope and depth of the agreement that runs well over 1,000 pages if one includes rules on market risk, operational risk, the leverage ratio and other minimum requirements. Four observations, however, are pertinent. The first is that Basel III is very complex in terms of data, analytics, implementation and reporting. It contains some untested and difficult to quantify provisions. Complexity will raise, not only the cost of bank compliance, but also the cost of enforcement to authorities. Some regulation, such as the countercyclical capital buffer, will require interpretation of macroeconomic data on the part of regulators and thus poses its own risks of implementation. Complexity will also force bank examiners to make more judgment calls. Consequently, regulatory discretion will rise; this, in turn, will not be uniform across nations. There is general acceptance that cross-country variation in risk-weighted assets reflects not only differences in business models, risk profiles and accounting rules but also different assessments of credit risk, and forbearance, by national regulators and supervisors. ${ }^{7}$ Different supervisory assessments, in turn, cannot be divorced from different national preferences for regulation and tradeoffs between regulation and important macro-economic objectives. Since regulatory stringency has a larger impact on bank lending in a bankcentric system than in a market-centric system, we would expect regulators and supervisors from bank-centric systems to be sensitive to this correlation and consequently behave

\footnotetext{
${ }^{7}$ Leslé and Avramova (2012) report on such differences using a sample of 50 large banks in the Asia Pacific region, Europe and North America.
} 
differently than their counterparts in market-centric systems. Furthermore, to the extent that national preferences about the trade-offs between regulatory stringency and bank lending differ, we would expect that supervisory assessments and enforcement will also reflect such differences; more on this below.

The second observation is that there are significant differences between the EU and the US in implementing Basel III. The US is more restrictive than the EU on capital requirements, liquidity requirements, leverage requirements, external credit ratings and loans secured by property. While the Dodd-Frank Act is the legislative tool responsible for most of these differences, the underlying impetus was the drive to regain reputation lost during the sub-prime mortgage crisis. In sum, the US is an example of a country that is not satisfied with the minimum standards agreed in Basel III. Other examples of more stringent regulation above international standards and faster implementation are Australia, Canada, Switzerland, some Scandinavian countries, and the United Kingdom. The third observation is that there are plenty of opportunities in the EU to deviate from the single rulebook. The position of the EU Commission, which is reflected in CRD IV, is to prohibit a race to the top in capital requirements because it would be against the interests of some member 
Table 1: Basel III implementation in the European Union and the United States (end 2013)

\begin{tabular}{|c|c|c|c|}
\hline Regulation & United States & European Union & Comment \\
\hline $\begin{array}{l}\text { CET } 1, \mathrm{~T} 1 \& \mathrm{~T} 2 \\
\text { ratios }\end{array}$ & $\begin{array}{l}\text { Ratios of } 4.5 \%, 6 \% \text { and } \\
8 \% \text { conform to Basel III } \\
\text { but additional restrictions } \\
\text { apply }\end{array}$ & $\begin{array}{l}\text { Ratios conform to } \\
\text { Basel III }\end{array}$ & $\begin{array}{l}\text { US has tighter restrictions } \\
\text { because of Dodd-Frank Act }\end{array}$ \\
\hline $\begin{array}{c}\text { Capital } \\
\text { conservation } \\
\text { buffer }\end{array}$ & $2.5 \%$ conform to Basel & $\begin{array}{l}2.5 \% \text { conform to Basel; } \\
\text { enforcement by } \\
\text { national supervisors }\end{array}$ & $\begin{array}{l}\text { Potential deviation from single } \\
\text { rulebook by EU member } \\
\text { countries }\end{array}$ \\
\hline $\begin{array}{l}\text { Countercyclical } \\
\text { capital buffer }\end{array}$ & $\begin{array}{l}2.5 \% \text { CET1 may apply } \\
\text { only to AAB banks }\end{array}$ & $\begin{array}{l}2.5 \% \text { CET1 apply to all } \\
\text { FIs; enforcement by } \\
\text { national supervisors }\end{array}$ & $\begin{array}{l}\text { Potential deviation from single } \\
\text { rulebook by EU member } \\
\text { countries }\end{array}$ \\
\hline $\begin{array}{l}\text { Systemic risk } \\
\text { buffer }\end{array}$ & Not yet decided & $\begin{array}{l}\text { National supervisors } \\
\text { have the power }\end{array}$ & $\begin{array}{l}\text { Potential deviation from single } \\
\text { rulebook by EU member } \\
\text { countries }\end{array}$ \\
\hline G-SIB surcharge & Not yet decided & $1 \%$ to $3.5 \%$ CET 1 & \\
\hline $\begin{array}{l}\text { Asset risk } \\
\text { weighting } \\
\text { methodology }\end{array}$ & $\begin{array}{l}\text { Standardized approach } \\
\text { obligatory, IRB can be } \\
\text { added }\end{array}$ & $\begin{array}{llr}\text { Standardized } & \text { and IRB } \\
\text { approaches may be } \\
\text { alternatives }\end{array}$ & \\
\hline $\begin{array}{l}\text { External credit } \\
\text { ratings }\end{array}$ & Not permitted & Permitted & US has tighter restrictions \\
\hline Sovereign debt & $\begin{array}{l}0 \% \text { US, } 20 \% \\
\text { conditional, } 0 \% \text { to } 150 \% \\
\text { non-US sovereigns }\end{array}$ & $\begin{array}{l}0 \% \text { EU governments, } \\
0 \% \text { to } 150 \% \text { non-US } \\
\text { sovereigns }\end{array}$ & $\begin{array}{l}\text { For non-home govts, EU follows } \\
\text { Basel II; US uses OECD } \\
\text { Country Risk Class. Codes }\end{array}$ \\
\hline $\begin{array}{l}\text { Loans secured by } \\
\text { property }\end{array}$ & $\begin{array}{l}50 \% \text { high quality, } 100 \% \\
\text { others }\end{array}$ & $35 \%$ & $\begin{array}{l}\text { US is more restrictive; potential } \\
\text { deviation from single rulebook } \\
\text { by EU member countries }\end{array}$ \\
\hline $\begin{array}{l}\text { Exposure in } \\
\text { default and } \\
\text { arrears }\end{array}$ & $\begin{array}{l}\text { US has higher weighting } \\
\text { than EU }\end{array}$ & $\begin{array}{l}\text { US has higher } \\
\text { weighting than EU }\end{array}$ & \\
\hline Equity exposure & $\begin{array}{l}\text { US has tighter restrictions } \\
\text { than EU }\end{array}$ & $\begin{array}{l}\text { US has tighter } \\
\text { restrictions than EU }\end{array}$ & \\
\hline Off-balance sheet & US and EU are similar & US and EU are similar & \\
\hline $\begin{array}{l}\text { Securitized } \\
\text { transactions }\end{array}$ & $\begin{array}{l}\text { Not yet compliant with } \\
\text { Basel III }\end{array}$ & $\begin{array}{l}\text { Compliant with Basel } \\
\text { III }\end{array}$ & $\begin{array}{l}\text { US non-compliance stems from } \\
\text { not referring to external credit } \\
\text { ratings }\end{array}$ \\
\hline $\begin{array}{l}\text { Derivatives - } \\
\text { OTC }\end{array}$ & $\begin{array}{l}\text { US follows a different } \\
\text { approach than Basel III }\end{array}$ & EU follows Basel III & Different approaches \\
\hline $\begin{array}{c}\text { Credit valuation } \\
\text { adjustment }\end{array}$ & US follows Basle III & $\begin{array}{l}\text { EU does not follow } \\
\text { Basel III }\end{array}$ & Different approaches \\
\hline $\begin{array}{l}\text { Liquidity } \\
\text { requirement }\end{array}$ & $\begin{array}{l}\text { US goes beyond Basel III } \\
\text { because of Dodd-Frank } \\
\text { Act }\end{array}$ & EU follows Basel III & US has tighter restrictions \\
\hline $\begin{array}{l}\text { Leverage } \\
\text { requirement }\end{array}$ & $\begin{array}{l}4 \% \text { for depository } \\
\text { institutions; } 3 \% \text { for AABs }\end{array}$ & $3 \%$ & $\begin{array}{l}\text { US has tighter restrictions, but } \\
\text { new developments in the making }\end{array}$ \\
\hline
\end{tabular}

Sources: Shearman and Sterling (2013); website of the Board of Governors of the Federal Reserve System. Notes: CET1= common equity tier 1 capital; T1= tier 1 capital; T2=tier 2 capital; $\mathrm{AAB}=\mathrm{Advanced}$ Approaches Bank; $\mathrm{FI}=$ financial intermediary; $\mathrm{G}-\mathrm{SIB}=$ globally systemically important banks; IRB= internal ratings based. 
countries and would encourage regulatory arbitrage. ${ }^{8}$ Yet, in Table 1 , we have identified at least three areas -the capital conservation buffer, the countercyclical capital buffer, and loans secured by property-where national regulators and supervisors can exercise discretion. The extent of this discretion, as we have mentioned in the previous paragraph, will depend on national preferences for regulation and the nature of the tradeoff between regulation and other economic objectives. It should be noted that in October of 2014 the ECB will become the single supervisors of EZ banks with assets larger than $€ 30$ billion or a market value greater than 20 percent of the home country's GDP. For this relatively small group of banks (approximately 150) we would expect the single rulebook to apply. The last observation concerns exposures to sovereign debt. While there are some differences between the EU and the US, the common and sharp anomaly is to treat sovereign debt as riskless. Furthermore, concentration risk does not apply to government securities unlike corporate securities. This is a significant issue as government securities are also used widely as collateral, for pledging to central banks and clearing houses. The EU applies zero weighting, not only to EU member states, but also to all OECD countries, as was true in Basel I and II. The US relies on the Country Risk Classification Codes of the OECD to calculate risk weighting. Neither area "legislates" a home bias in the treatment of sovereign risk, but in fact banks have a distinct preference for domestic sovereigns over foreign sovereigns for strategic reasons, such as being considered too big to fail, the need for greater local currency liquid assets, foreign exchange risk and potential preferential treatment by domestic governments in case of debt restructuring. To regulate the complete

\footnotetext{
${ }^{8}$ Empirical evidence of regulatory arbitrage emerges from an examination of cross-border mergers and acquisitions (Carbo-Valverde et al. 2012; Karolyi and Taboada 2013). Abnormal rates of returns are observed around announcement dates for acquiring banks located in countries with higher regulation and supervision.
} 
"safety" of debt sovereigns in light of what has happened in Europe is no longer justifiable. EBA (2013b) reports for 64 large banks, at the end of June of 2013, an exposure to sovereign debt of $€ 1,585$ billion, of which 68 percent issued by domestic governments. For Italian and Spanish banks sovereign debt exposure represents approximately 10 percent of total bank assets. This issue has not come to rest and will feature in stress tests of European banks as well as in regulatory initiatives.

On January 12, 2014, the Group of Governors and Heads of Supervision endorsed the new softer BCBS guidelines concerning the leverage ratio and the net stable funding ratio. For the leverage ratio, the softening comes, not simply from a lower value of the ratio, although they have aimed for a low calibration, but through changes on the calculation itself of what qualifies as assets. Limited netting (i.e., difference between assets and liabilities relative to a given counterparty) will be permitted on transactions such as repos and reverse repos, thus reducing the denominator of the leverage formula. Yet many financial losses have occurred because management and supervisors concentrated on the lower value of net positions without observing the larger gross positions, as in the case of Barings and Société Générale. Derivatives will be counted on a net basis, again lowering the denominator of the formula. On the net stable funding ratio, the changes would allow including funding with maturities slightly less than a year. It should be stressed that US, UK and some other regulators desire tighter standards and are not favorable to a dilution of the leverage ratio, which is preferred to risk-weighted measures that can be easily "gamed" by banks (Jones 2014). ${ }^{9}$

\footnotetext{
${ }^{9}$ Andrew Haldane, the director for financial stability at the Bank of England, has proposed a simplification of capital ratios (Jones 2014). Note that British and Swiss banks have tighter liquidity rules than those of Basel III. Switzerland is a member of the European Economic Space as an ex
} 


\section{IV.EUROZONE ASYMMETRIES AND REGULATION HETEROGENEITY}

In this section we discuss three issues: to what extent the oligopoly model applies to the EZ where the largest countries are tied to the smallest ones by a currency union and a high degree of financial integration; does a currency union enhance the relative power of fiscally undisciplined countries?; and will the single rulebook survive different national preferences for regulation and tradeoffs with other important macroeconomic variables?

\section{Eurozone Asymmetries}

The Eurozone has never met, even loosely, the conditions for an optimal currency area. The drafters of the Maastricht Treaty were aware of this but were driven by political motivation and by the expectation that fiscal and political union would follow monetary union in nonbiblical times. History proved them wrong and the EZ architecture has remained incomplete and fragile. The North of Europe is very different from the South: it is, not only in terms of fiscal profligacy, but also with respect to competitiveness that shows up in external imbalances (Alessandrini et al. 2014). Many of the characteristics typical of the Italian Mezzogiorno problem have resurfaced in the EZ, except that the mechanism to stabilize a monetary union that is also a fiscal union is absent in the EZ. The upshot is that the latter resembles more an inter-governmental agreement than a supranational entity.

As a magnified inter-governmental agreement, the EZ illustrates the fundamental difference between creating a club and managing it. France and Germany, large countries,

EFTA member. Both countries raised their requirements prior to the publication of the international rules because both faced large domestic financial risks with banking assets many times that of GDP. 
were the impetus behind the creation of the monetary union; the smaller countries could not have pulled it off. The payoff for the large countries was trade deepening and financial integration. The payoff for the small countries was lower interest rates from higher collective credit ratings and the elimination of currency risk to investors. As to credit risk, the club set rules to reduce the likelihood that profligate member countries would damage the monetary union: the two most important ones were restrictions on government deficits and the introduction of an anti-solidarity norm aimed at insulating the club from the spillovers of a member's default. ${ }^{10}$ But the rule on deficits was not seriously enforced and the anti-solidarity rule was not taken as fully credible by the markets. The periphery rode freely on the lower interest rates achieved by the center and postponed needed adjustments and reforms. Neither the club nor its large members took actions to remedy this classic flaw of club behavior. The financial crisis, but especially the revelation of Greece's fiscal disarray at the end of 2009 , unequivocally showed the deep cracks in the monetary union house.

To summarize the main lesson of club behavior, peripheral countries have exerted disproportionate power in relation to the size and relevance of their economies and financial centers. This is typical free riding emphasized by Olson (1965), Mancur Olson and Richard Zeckhauser (1966), and Fratianni and Pattison (1982). Casella (1992) provides an alternative explanation for the disproportionate power of small players: “...In a cooperative agreement, if power were proportional to size, small countries would have very little control over common decisions; they would be bound by the discipline of the accord without being able to address their own specific interests." It is correct that the EZ is a

\footnotetext{
${ }^{10}$ Art.104 of the EU Treaty deals with fiscal rules and their enforcement; Art. 103 states the no bail out clause (also known as the non-solidarity clause), but Art. 100 introduces conditions for solidarity.
} 
voluntary agreement and all participants must feel they have a say in this agreement. On other hand, the EZ, unlike other clubs, has no expulsion clause. A non-compliant member cannot be kicked out. The exit door is open only for those who voluntarily take it. By the time the damage is revealed it may be too costly for the large, compliant, countries to pull out and form another, more homogeneous, monetary club. This is what happened with Greece in 2010: Greek bonds were held by EZ banks, especially those located in France and Germany, as well as by the ECB. A Greek default and a break in the monetary union would have undermined the capitalization of EU financial institutions, which had already been debilitated by the sub-prime mortgage crisis. The outcome was that the large countries put together a package for the support of Greece and its creditors. ${ }^{11}$

\section{$\underline{\text { Regulation Heterogeneity }}$}

Having noted the inherent asymmetries among the members of the monetary union, the question is whether the single rulebook of financial regulation will survive. With monetary union, monetary policy is common to all member countries. Without a centralized government budget and a transfer mechanism that compensates for asymmetric national shocks, member countries must rely on national fiscal policy for countercyclical policy. However, since the Greek shock the prevailing regime has been one of fiscal austerity. ${ }^{12}$ The single rulebook would impose another common standard across heterogeneous countries. Common financial regulations, in addition to a common monetary policy and constrained fiscal policy, would reduce further the few degrees of freedom left to national

\footnotetext{
${ }^{11}$ It is fair to say that the concern over German and French banks, among others, holding large holdings of Greek government debt was the primary motive for the speed and size of the Greek "rescue" package.

${ }^{12}$ As a reflection of the prevailing mood of the times, when Greece's premier George Papandreou asked for easier borrowing terms, German Chancellor Angela Merkel said:"We want to make sure nobody else will want this." (The Guardian, 8 November 2012). We thank the referee for this point.
} 
macroeconomic policy. Indeed, it is quite likely that the single rulebook may be applied badly in the absence of a more federal EU.

Country heterogeneity and different tradeoffs between prudential financial regulation and attempts to affect national economic activity encourage deviations from the single rulebook. The evidence shows that gains from coordination of regulation occur when shocks are symmetric (Masson and Pattison 2009). If shocks are vastly different, instead, the small country may have little or no incentive to cooperate. In the case of complete globalization, a high degree of competition amongst countries triggers incentives to harmonize regulation to prevent a race to the bottom. This is the principle underlying the EU implementing directives for minimum regulation of many industries, notably banking. Basel III is another example, but, as we have shown, the web of regulation is so complex that it would be easy for institutions or national regulators to cheat. The nexus between complexity and difficulty of monitoring uniformity may reflect the role of national asymmetries and why so many countries have announced a willingness to follow Basel III. Here are some examples of heterogeneous application of regulation and supervision:

1. The EBA carries out periodic investigations into the implementation of regulation such as the consistency of risk-weighted assets. It reports significant variation in risk weights arising from estimated parameters, such as the probability of default and the loss given default. It has also seen a wide array of practices for defining these measurements. Moreover, the EBA highlights (2013a:28): "it appears very difficult to distinguish between the factors determining these differences...may require further investigation and possibly supervisory measures to foster convergence." In other words, it is difficult to implement and monitor a common rule book and to assess the quality of national regulation and supervision.

2. A common method to deviate from a common rule is for banks to change how riskweighted assets are calculated (Le Leslé and Avramova 2012).Vaughan (2011) reports that, faced with higher capital requirements, banks were reluctant to cut dividends or bonuses, while governments did not want them to reduce lending. Italian, German, Spanish, and UK banks were changing risk-weight-based modeling 
to improve their capital positions. The share of risk-weighted assets to total assets for European banks was half that of American banks. Within Europe, cross-country variation was large, ranging from 31 percent of French and Benelux banks to 52 percent of Spanish banks. An earlier EBA study found that "some banks were using risk models that required them to hold 70 percent less capital than their peers" (Masters, 2013:13). ${ }^{13}$

3. Basel III prescribes that banks must hold more capital on their exposure to derivative contracts. Fonte (2013) reports on a method to circumvent the rule. The Italian Treasury is planning to introduce a new system of guarantees that would lower the cost to banks "to negotiate derivative contracts with the Treasury over government bonds, potentially increasing their ability to buy Italian debt... Under the new system, outlined in a draft decree linked to the budget law that parliament must pass by year-end, the Treasury and the banks will exchange cash sums on a short-term basis to guarantee their respective derivatives positions, based on their mark-to-market value... The draft bill said the new system was in accordance with International Monetary Fund recommendations, adding it had been recently introduced in Britain while Sweden had used it for a long time."

4. Accounting profits are sensitive to loan loss provisions, which in turn depend on the criteria used by bank examiners to judge non-performing loans. Banca d'Italia (2013:28-29) acknowledges a much stricter prudential rule than elsewhere in the EZ and has calculated that if the foreign criteria had been applied instead of her own, the ratio of non-performing loans to total loans in Italian banks, as of June 2012, would have dropped by approximately 4 percentage points.

5. Another source of country heterogeneity is the treatment of deferred tax assets that result from losses that may be applied to future earnings. Under Basel III, deferred tax assets do not count towards capital. ${ }^{14}$ Nonetheless, it is still worth noting different practices aimed at "enhancing" banks' balance sheets. Italy allowed banks to reclassify deferred tax assets as tax credits. Spanish banks had $€ 50$ billion of deferred tax assets and lobbied with the government to follow the Italian example. Buck (2013b:14) reports that deferred tax assets made up 83 percent of tangible book value for one bank and 64 percent for another. This would be either a deviation from the new global Basel rules or would imply a higher public debt by an equivalent amount.

6. Another example of heterogeneity occurred in January of 2014, when a new Italian decree-law revalued the shares of Banca d'Italia--owned by a select group of banks, insurance companies and a couple of public institutions-from an aggregate value

\footnotetext{
${ }^{13}$ The analytics and data are so demanding that it is virtually impossible for outsiders to assess individual institutions.

${ }^{14}$ They are uncertain since a weak bank could fail before it had earned enough to utilize the tax assets.
} 
of $€ 156,000$ to $€ 7.5$ billion. The shares will also be entitled to a maximum annual dividend of 6 percent of the revalued shares (Visco 2013). This decree-law has been very controversial because it is seen as an artificial boost to the balance sheet and income statement of those banks that are big owners of Banca d'Italia shares (Coltorti 2013). ${ }^{15}$ Furthermore, capital gains on these shares booked at fair value will be included in Common Equity Tier 1 capital. ${ }^{16}$

7. Authorities use stress tests to signal the soundness of the banking system. Early European stress tests were of questionable value. Within four months of stress tests done in 2010, two Irish banks that passed the test were in difficulty (Jenkins 2010: 2). One bank that passed the test with 6.5 percent Tier 1 capital ratio subsequently failed. Some countries refused to publish details of their stress tests. Many used lenient stresses. Each country regulator was allowed to apply its own stresses subject to guidance from the then European regulatory committee. The timing of the test can be set strategically. Smyth (2013:14) reports that "Dublin has won approval from international lenders to delay the next round of banking stress tests until 2014, despite concerns over the health of banks...The new round of stress tests would likely impose lower capital requirements on Irish banks, compared with the minimum 10.5 per cent core tier one capital set in the last stress tests in 2011." Still another example is "extend and pretend". By this method banks roll over loans before maturity so that loans cannot be classified as in default or in arrears (Buck 2013a:15).

\section{V.CONCLUSIONS}

Since Basel I financial regulation has shifted from oligopoly clubs managed by the largest countries to expansive clubs (committees). Expansive clubs are more difficult to create and, once created, are more costly to manage and generate consensus. More importantly, an expansive club has to agree to terms that are closer to the preferences of soft-regulation members than of strict-regulation members. Yet, once a "global" agreement, such as Basel III, is reached, the transposition is left to national or regional regulators. It is in this

\footnotetext{
${ }^{15}$ The other objection is that this decree law abrogates a law of 2005, which has never been enforced, that would transform the Banca d'Italia as a state-owned institution. Intesa San Paolo owns $42.4 \%$ of the shares, Unicredit $22.1 \%$ and Generali $6.37 \%$. The new law prescribes a maximum ownership concentration of $3 \%$, which means that a sizeable capital gain can be realized from the sale of the excess shares. The ECB has objected to the decree-law on several grounds but also because Banca d'Italia may be induced to be a buyer of those excess shares at above-market values.

${ }^{16}$ Inclusion in CET1 is also permissible if shares are booked as available for sale, starting in 2015 (Visco 2013).
} 
implementation stage as well as supervision, monitoring and enforcement that deviations from Basel III standards are bound to occur. This is an issue not only for the entire membership of the BCBS but also for the sub-group consisting of EU member countries. In each case the difficulties of achieving agreements will lead to lower standards. This fundamentally threatens cooperation within the larger global clubs such as the BCBS if some countries financial institutions are seen to be able to operate with more favorable rules.

In the paper we have emphasized two important sources of deviations from the Basel III global rules. The first is the difference between the EU and the US. The EU has adopted minimum regulatory standards and a single rulebook to be consistent with the principle of the single market: a "race to the top" would have undermined such a principle and given rise to political dissent and regulatory arbitrage. The US, a financial center country seeking to repair the reputational damage of having started the sub-prime financial crisis, wants to set tighter standards than Basel III. While we have not discussed it, the UK, Canada and Switzerland are more in line with the US in setting higher standards than the EU. The second is deviations across EU members, in particular members of the EZ, driven by differences in country characteristics, regulatory preferences, and tradeoffs between regulatory stringency and economic activity. The dictates of a monetary union without a fiscal union have reduced the degrees of freedom to national policymakers who may seek to offset them by a more flexible interpretation of global rules of regulation and supervision. The complexity of Basel III will facilitate this process, as demonstrated by the numerous examples we have offered. 
On the other hand, one cannot rule out that the EU as a whole may ultimately compromise on global prudential standards and its already delayed timetable to revitalize economic activity and narrow existing national asymmetries. In February 2014, it was reported that the European Commission was willing to accept securitizations in liquidity buffers even though the European Banking Authority "put most securitizations in the lowest possible liquidity category" (Sanderson 2014:1). The increasing difficulty to initiate, monitor and discipline global standards makes them vulnerable to deviations.

The European Union purports to adopt guidance from the BCBS. Yet, the EU supports weaker regulation and more delayed implementation than is generally favored by other members of the BCBS or FSB. Furthermore, the EU seems prepared to compromise on global prudential standards adopted within its jurisdiction, while BCBS and EBA monitor adherence to their standards. This suggests a collision between clubs if monitoring is credibly and transparently carried out.

Finally, in the event that EU leaders may decide to enforce a uniform rulebook, the risk will be that it be applied badly in the absence of a comprehensive banking union and a complete fiscal union.

\section{References}

Alessandrini, Pietro, Fratianni, Michele, Hallett, Hughes Andrew and Andrea Presbitero, 2014 forthcoming, External imbalances and fiscal fragility in the euro area, Open Economies Review, DOI 10.1007/s11079-013-9305-5.

Banca d'Italia (2013), Rapporto sulla stabilità finanziaria, n. 5, April. 
Bank for International Settlements (2014), Important steps towards completion of postcrisis regulatory reforms endorsed by Group of Governors and Heads of Supervision, 12 January; available at http://www.bis.org/press/p140112.htm

Basel Committee on Banking Supervision (2013), Report to G20 leaders on monitoring and implementation of Basel III regulatory reforms, August.

Bayne, Nicholas (2005), "Do we Need the G8 Summit? Lessons from the Past, Looking Ahead to the Future", in M. Fratianni, J. Kirton, A. Rugman and P. Savona (eds.) New Perspectives on Global Governance", Aldershot: Ashgate.

Bloomberg (January 7, 2013), Banks win 4-year delay as Basel liquidity loosened.

Board of Governors of the Federal Reserve System, Basel Regulatory Framework, http://www.federalreserve.gov/bankinforeg/basel/USImplementation.htm\#baseIII).

Boughton,James M., 2001, Silent revolution: The International Monetary Fund 1979-1989, Washington D.C., International Monetary Fund, Publication Services.

Buck, Tobias, 2013a, "Spanish banks face $€ 10$ bn bad loans gap”, Financial Times, May 24, 15.

Buck, Tobias, 2013b, "Spanish lenders on brink of tax win", Financial Times, September $12,13$.

Carbo-Valverde, S., Kane, E.J., Rodriguez-Fernandez, F., 2012, Regulatory arbitrage in cross-border banking mergers within the EU. Journal of Money, Credit, and Banking 44:1609-1629.

Casella, Alessandra (1992), Participation in a currency union, The American Economic Review, 82(4): 847-863.

Coltorti, Fulvio (2013), Quel pasticciaccio brutto di via Nazionale, Linkiesta, 15 december; available at www.linkiesta.it/bankitalia-privati.

Council of the European Union (2009), European Council of 18/19 June 2009, Presidency Conclusions, Brussels, 11225/2/09 REV 2.

Dellas, Harris and Tavlas, George (2013), The gold standard, the euro and the origins of the Greek sovereign debt crisis, Cato Journal, 33(3): 491-520.

European Banking Authority (2013a), Interim results of the EBA review of the consistency of risk weighted assets, Bruxelles, 26 February. 
European Banking Authority (2013b), EU-wide transparency exercise 2013- Summary Report, Bruxelles, 16 December.

European Commission (2013a), A comprehensive EU response to the financial crisis: a strong financial framework for Europe and a banking union for the eurozone. Brussels, July 10.

European Commission (2013b), CRD IV, http://ec.europa.eu/internal_market/bank/regcapital/legislation_in_force_en.htm\#ma incontentSec1

Fonte, Giuseppe (2013), Italy plans to offer guarantees on government bond derivatives, Reuters, 21 October; http://www.reuters.com/article/2013/10/21/italy-derivativesguarantees-idUSL5N0IB1XE20131021

Fratianni, Michele and John Pattison (1982), "The Economics of International Organizations", Kyklos, 35(2), 244-262.

Fratianni, Michele and John Pattison (2001), "The Bank for International Settlements: An Assessment of its Role in International Monetary and Financial Policy Coordination", Open Economies Review, 12, 2, April, 197-222.

Guardian (8 November 2012), Greece's austerity: democracy tested to destruction.

Jenkins, Patrick (2010), "Doubts resurface on credibility of stress tests", Financial Times, 24 November: 2.

Jones, Huw (2014), Regulators ease new bank rule on leverage to aid economy, Reuters, 12 January; available at http://www.reuters.com/article/2014/01/12/us-basel-banksidUSBREA0B0IX20140112

Karolyi, G. Andrew and Alvaro G. Taboada, 2103, Regulatory arbitrage and cross-border bank acquisitions, unpublished paper, October

Kindleberger, Charles (1983), Standards as public, collective and private goods", Kyklos, 36(3): 377-396.

Kirton, John J. (2013), G20 governance for a globalized world, Ashgate.

Kupiec, Paul H. (2013), Basel III: Some costs will outweigh the benefits, American Enterprise Institute, Financial Services Outlook, November.

Le Leslé, Vanessa and Sofiya Avramova (2012), Revisiting risk-weighted assets -Why do RWAs differ across countries and what can be done about it?, International Monetary Fund, WP 12/90. 
Masson, Paul and John Pattison (2009), "Financial Regulatory Reform: Using Models of Cooperation to Evaluate Current Prospects for International Agreement", Journal of Economic Asymmetries, 5, 3, 119-136.

Masters, Brooke, 2013, "Bank risk weightings in spotlight after EBA uncovers discrepancies", Financial Times, February 27, 13.

Merler, Silvia, Pisani-Ferry, Jean, 2012, Sudden stops in the Euro area, Review of Economics and Institutions, 3(3): Article 5.

Olson, Mancur Jr. (1965), The Logic of Collective Action, Cambridge: Harvard University Press.

Olson, Mancur Jr. and Richard Zeckhauser (1966), An economic theory of alliances, Review of Economics and Statistics, 48(3): 266-279.

Rachman, Gideon (2013), "Old alliance gives west a chance for final stand", G8 Summit, in Financial Times, June 17, 1.

Sanderson, Owen (2014), "EC takes securitization further down rehab path", February 14, www.reuters.com/assets/print?aid=USL5NOLF1EU20140214

Shearman \& Sterling LLP (2013), Basel III framework: US/EU comparison, 17 September.

Smyth, Jamie, 2013, "Ireland allowed to delay bank tests", Financial Times, June 14, 14.

Vaughan, Liam, 2011, "Financial Alchemy Foils Capital Rules as Banks Redefine Risk", Bloomberg, November 9, www.bloomberg.com/print/2011-11-09/financialalchemy... )

Visco, Ignazio (2013), Indagine conoscitiva per l'istruttoria legislativa sul disegno di legge n. 1188, Audizione del Governatore della Banca d'Italia al Senato della Repubblica, 12 December. 
APPENDIX, Table 1A: Countries and Clubs, weights are percent of world GDP

\begin{tabular}{|c|c|c|c|c|}
\hline Country's club membership & Country & $\begin{array}{l}\text { GDP } \\
\text { weight }\end{array}$ & $\begin{array}{l}\text { Bank credit } \\
\text { weight }\end{array}$ & $\begin{array}{l}\text { Stock value } \\
\text { traded weight }\end{array}$ \\
\hline G20, FSB, BCBS & Argentina & 0.66 & 0.14 & 0.00 \\
\hline G20, FSB,BCBS & Australia & 2.12 & 1.93 & 2.02 \\
\hline G10, BCBS & Belgium & 0.67 & 0.46 & 0.20 \\
\hline G20, FSB,BCBS & Brazil & 3.11 & 2.03 & 1.60 \\
\hline G7, G10,G20, FSB, BCBS & Canada & 2.51 & NA & 2.32 \\
\hline G20, FSB, BCBS & China & 11.36 & 10.43 & 11.19 \\
\hline G5, G7, G10, G20, FSB, BCBS & France & 3.61 & 2.91 & 2.16 \\
\hline G5, G7, G10, G20, FSB, BCBS & Germany & 4.73 & 3.43 & 2.35 \\
\hline FSB, BCBS & Hong Kong & 0.36 & 0.43 & 2.36 \\
\hline G20, FSB, BCBS & India & 2.54 & 1.15 & 1.20 \\
\hline G20, FSB, BCBS & Indonesia & 1.21 & 0.31 & 0.18 \\
\hline G7, G10, G20, FSB, BCBS & Italy & 2.78 & 2.76 & 1.46 \\
\hline G5, G7, G10, G20, FSB, BCBS & Japan & 8.23 & 16.86 & 6.93 \\
\hline G20, FSB, BCBS & S. Korea & NA & NA & NA \\
\hline BSBC & Luxembourg & 0.08 & 0.08 & 0.00 \\
\hline G20, FSB, BCBS & Mexico & 1.63 & 0.45 & 0.23 \\
\hline G10, FSB, BCBS & Netherlands & 1.06 & 1.36 & 0.85 \\
\hline G8, G20, FSB,BCBS & Russia & 2.78 & 0.68 & 1.41 \\
\hline G20, FSB, BCBS & S. Arabia & 0.98 & -0.06 & 0.99 \\
\hline FSB, BCBS & Singapore & 0.38 & 0.22 & 0.30 \\
\hline G20, FSB, BCBS & S. Africa & 0.53 & 0.59 & 0.60 \\
\hline BCBS & Spain & 1.83 & 2.44 & 2.07 \\
\hline G10, BCBS & Sweden & 0.72 & 0.62 & 0.72 \\
\hline G10, FSB, BCBS & Switzerland & 0.87 & 1.00 & 1.23 \\
\hline G20, FSB, BCBS & Turkey & 1.09 & 0.46 & 0.67 \\
\hline G5, G7, G10, G20, FSB, BCBS & U. K. & 3.41 & 4.18 & 4.78 \\
\hline G5, G7, G10, G20, FSB, BCBS & U.S & 22.42 & 30.43 & 41.06 \\
\hline
\end{tabular}

Data source: World Bank, World Development Indicators, http://data.worldbank.org/products/wdi.

Notes.The data refer to 2012. G10 started in 1961 France, Germany, Japan, the UK and the US (later to become G5) plus Canada and Italy (later these seven would form G7) plus Belgium, Netherlands, and Sweden. Switzerland became an affiliated member in 1964; thus G10 is in fact G11. The initial objective of the group was to organize and fund the General Arrangements to Borrow, a facility that permitted the IMF to borrow from member country governments to finance the lending activity of the Fund. G10 has also played a leading role in the OECD ( in particular in its Economic Policy Committee and Working Party 3) and in the Bank for International Settlements where the G-10 central banks meet once a month. G5 started informally in 1973 when the US Treasury invited their counterparts in France, Germany and the UK to the White House (hence the nickname "Library Group") to discuss the repercussion of the demise of Bretton Woods. Japan joined later in the year. The collapse of the fixed exchange rate system was also responsible for the creation of G7 at the Rambouillet meeting in France in 1975. G20 started in 1999 with the objective of consulting and cooperating on issues related to the international financial system; for an extensive treatment of G20, see Kirton (2013). FSB is the brainchild of G20 at its 2009 meeting in London with a mandate of monitoring and proposing recommendation on the world's financial system. BCBS was established in 1974 by the G10 central banks. It is composed of supervisory authorities. 
Table 1B: Clubs and BCBS: world shares of critical indicators, percent

\begin{tabular}{|c|c|c|c|c|c|c|c|c|}
\hline & & GDP in & JS dollars & $\begin{array}{l}\text { Domest } \\
\text { GDP }\end{array}$ & bank cre & lit, \% & Stocks $\mathrm{t}$ & led, \% GDP \\
\hline & 1973 & 2007 & 2012 & 1973 & 2007 & 2012 & 2007 & 2012 \\
\hline G5 & 58.63 & 48.86 & 42.40 & 71.28 & 66.09 & 57.82 & 65.22 & 57.28 \\
\hline $\mathrm{CAN}+\mathrm{IT}$ & 6.51 & 6.29 & 5.30 & 5.86 & 5.46 & 2.76 & 3.90 & 3.78 \\
\hline $\mathrm{BE}+\mathrm{NL}+\mathrm{SW}+\mathrm{CH}$ & 3.72 & 3.82 & 3.33 & 2.68 & 3.84 & 3.44 & 4.73 & 3.00 \\
\hline BRIC countries & 6.62 & 13.10 & 19.79 & 1.49 & 7.53 & 14.30 & 10.08 & 15.40 \\
\hline Remaining G20 & 5.62 & 6.97 & 8.21 & 2.44 & 3.16 & 3.83 & 2.92 & 4.68 \\
\hline Additional BCBS & 1.98 & 3.32 & 2.65 & 1.66 & 3.68 & 3.18 & 4.20 & 4.73 \\
\hline Rest of the world & 16.92 & 17.65 & 18.33 & 14.59 & 10.25 & 14.68 & 8.94 & 11.13 \\
\hline
\end{tabular}

Sources: World Bank, World Development Indicators, http://data.worldbank.org/products/wdi.

Notes. G5 consists of France, Germany, Japan, the United Kingdom, and the United States; CAN = Canada, $\mathrm{IT}=$ Italy, $\mathrm{BE}=$ Belgium, $\mathrm{NL}=$ Netherlands, $\mathrm{SW}=$ Sweden, $\mathrm{CH}=$ Switzerland; $\mathrm{G} 7=\mathrm{G} 5+$ $\mathrm{CAN}+\mathrm{IT} ; \mathrm{G} 10=\mathrm{G} 7+\mathrm{NE}+\mathrm{NL}+\mathrm{SW}+\mathrm{CH}$; BRIC countries: Brazil, Russia, India and China; Remaining G20 = Argentina, Indonesia, S. Korea, Mexico, S. Arabia, S. Africa, and Turkey, G20 = G7 + BRIC countries + remaining G20; additional BCBS: Hong Kong, Luxembourg, Singapore, and Spain. Missing data: 1973, GDP for Russia and Switzerland; 1973, 2007 and 2012 GDP for S. Korea; 1973, bank credit for China. Hong Kong, Luxembourg, Russia, and Switzerland; 2012, bank credit for Canada.

Comments. In terms of world GDP shares, G5 has dropped from 53 percent in 1973 (the end of Bretton Woods) to 49 percent in 2007 (the year before the financial crisis) and to 42 percent in 2012 (five years into the crisis). The loss of G5 share finds a counterpart in the gain by emerging market economies, in particular the BRIC group. A relative decline has occurred also in terms of financial power. We measure financial power with two indicators: domestic bank credit and value of stock traded as a percentage of world GDP and normalized so that the shares add to 100 . The first indicator is biased in favor of bankcentric financial systems like Germany's; the second indicator is biased in favor of marketbased financial systems like the United Kingdom's. In terms of domestic bank credit world shares, G5 has dropped 71 percent in 1973 to 66 percent in 2007 and 58 percent in 2012; again, the financial crisis has sharply accentuated the decline. For the value of stocks traded, we have no data for 1973 and the comparison is limited to the recent past: G5 dropped from 65 percent in 2007 to 57 percent in 2012. The emerging market economies have picked most of the G5 losses in the two financial indicators. In sum, the relative decline of the traditional core industrial countries has been considerable, although more in the output market than in the financial markets. 